\title{
Prevalence and quantification of Listeria monocytogenes in beef offal at retail level in Selangor, Malaysia
}

\author{
Chee Hao Kuan ${ }^{1}$, Woan Chwen Wong ${ }^{1}$, Chai Fung Pui ${ }^{1}$, Nor Ainy Mahyudin ${ }^{1}$, \\ John Yew Huat Tang ${ }^{2}$, Mitsuaki Nishibuchi ${ }^{3}$, Son Radu ${ }^{1}$ \\ ${ }^{1}$ Food Safety Research Centre, Faculty of Food Science and Technology, University Putra Malaysia, \\ UPM Serdang, Selangor Darul Ehsan, Malaysia. \\ ${ }^{2}$ Faculty of Food Technology, Universiti Sultan Zainal Abidin, Kuala Terengganu, Terengganu Darul \\ Iman, Malaysia. \\ ${ }^{3}$ Center for Southeast Asian Studies, Kyoto University, Yoshida Sakyo-ku, Kyoto, Japan.
}

Submitted: July 22, 2011; Approved: April 04, 2013.

\begin{abstract}
A total of 63 beef offal samples (beef liver $=16$; beef lung $=14$; beef intestine $=9$; beef tripe $=15$; beef spleen $=9$ ) from three wet markets $(A, B$, and C) in Selangor, Malaysia were examined for the prevalence and microbial load of Listeria monocytogenes. A combination of the most probable number and polymerase chain reaction (MPN-PCR) method was employed in this study. It was found that L. monocytogenes detected in $33.33 \%$ of the beef offal samples. The prevalence of $L$. monocytogenes in beef offal purchased from wet markets A, B, and C were $22.73 \%, 37.50 \%$ and $41.18 \%$ respectively. The density of $L$. monocytogenes in all the samples ranged from $<3$ up to $>2,400 \mathrm{MPN} / \mathrm{g}$. The findings in this study indicate that beef offal can be a potential vehicle of foodborne listeriosis.
\end{abstract}

Key words: Listeria monocytogenes, most probable number (MPN), polymerase chain reaction (PCR), beef offal, prevalence.

\section{Introduction}

Listeria monocytogenes is a Gram-positive, facultative anaerobic, non-spore forming foodborne pathogen which can cause a severe illness of listeriosis. Although listeriosis is relatively rare, it accounts for high fatality rate (30\%) especially in YOPI (young, old, pregnant, immunodeficient) groups (Broome et al., 1990; Berche 2005; Painter and Slutsker, 2007). This ubiquitous bacterium is widespread in the environment. In the last two decades, $L$. monocytogenes has caused in a high number of listeriosis outbreaks throughout the world and it was associated with various foods, including chocolate milk in United States of America, butter in Finland and cheese in Japan (Dalton et al., 1997; Lyytikäinen et al., 2001; Makino et al., 2005). So far, listeriosis outbreak has not been reported in Malaysia. Previous studies have reported that $L$. monocytogenes has been found in poultry, seafood and vegetables in Malaysia over the past 15 years (Arumugaswamy et al., 1994;
Endang et al., 2003; Jeyaletchumi et al., 2010b). Therefore, listeriosis might occur in Malaysia but deemed to be undetected due to the difficulty in identification L. monocytogenes which is closely similar with other Listeria spp. in term of morphology and biochemical properties (Liu 2006).

Internal organs of animal such as liver, spleen, lung, tripe and intestine can be the sources of $L$. monocytogenes. Arumugaswamy et al. (1994) reported that higher prevalence $(63 \%)$ of L. monocytogenes was detected in chicken parts, liver and gizzard in Malaysia. The safety level of $L$. monocytogenes in beef offal is a great concern due to the eating habits of Malaysians. In Malaysia, beef offal is very popular as fried or in soups and almost all of the parts of the beef can be eaten. It can be easily obtained from wet markets with a cheap price. However, the hygienic conditions of these wet markets are poor which can increase the cross contamination rate and contributing to higher prevalence of L. monocytogenes. 
Conventional methods for the detection of L. monocytogenes involve selective enrichment with subsequent selective plating, followed by serological confirmation and/ or biochemical screening are considered as time consuming process (Jeyaletchumi et al., 2010a). In this study, most probable number (MPN) method together with polymerase chain reaction (PCR) method was used for the quantitative detection of L. monocytogenes in beef offal samples. MPN-PCR has been proven to be a rapid method with higher accuracy in the detection of species specific genes of foodborne pathogens (Chai et al., 2007; Su and Liu, 2007).

Although many studies have been carried out on the L. monocytogenes in different food products, there is limited data available on the prevalence of $L$. monocytogenes in animal offal. This study is aimed to determine the prevalence and microbial load of L. monocytogenes in beef offal by using the MPN-PCR method to obtain more information for the food safety risk assessment analysis thereby raise awareness among the consumers on the consumption of this type of food.

\section{Materials and Methods}

\section{Sample collection}

From December 2010 to February 2011, a total of 63 beef offal samples were randomly purchased from wet market A, B, and C respectively in Selangor, Malaysia. During sampling, all the samples were transported to the laboratory in an ice box and analyzed immediately.

\section{Detection and enumeration of $L$. monocytogenes by MPN-PCR method}

A $10 \mathrm{~g}$ of beef offal sample was aseptically weighed and added to $90 \mathrm{~mL}$ of Listeria Enrichment Broth (LEB, Merck) in stomacher bag and homogenized using stomacher for $2 \mathrm{~min}$. The pre-enriched bacterial culture was then incubated at $30{ }^{\circ} \mathrm{C}$ for $4 \mathrm{~h}$. Then, the selective agents (acriflavin, $10 \mathrm{mg} / \mathrm{L}$; sodium nalidixate, $40 \mathrm{mg} / \mathrm{L}$; cycloheximide $50 \mathrm{mg} / \mathrm{L}$ ) were added. For three-tube MPN analysis, $1 \mathrm{~mL}$ of the 10-fold, 100-fold and 1000-fold dilutions of the enriched bacteria culture were incubated for another $44 \mathrm{~h}$ at $30^{\circ} \mathrm{C}$, then $0.1 \mathrm{~mL}$ was taken from each tube and plated on PALCAM Listeria-selective agar (Merck) before incubated for $48 \mathrm{~h}$ at $30{ }^{\circ} \mathrm{C}$. At least five presumptive colonies (grey-green colonies with black zones) were picked and plated onto Tryptic Soy Agar (TSA; Difco ${ }^{\mathrm{TM}}$ ) for purification before undergoing confirmatory tests.

The turbid MPN tubes and presumptive colonies on TSA agar were subjected to DNA extraction by using boiled cell method (Chai et al., 2007; Jeyaletchumi et al., 2010 b). A $500 \mu \mathrm{L}$ portion of each broth was centrifuged at $13,400 \mathrm{~g}$ for $1 \mathrm{~min}$, and the pellet was resuspended in $500 \mu \mathrm{L}$ of sterile distilled water. The mixture was homogenized by using vortex and boiled for $10 \mathrm{~min}$. Then, the cell suspension was cooled at $-20^{\circ} \mathrm{C}$ for $10 \mathrm{~min}$ before it was centrifuged at 13,400 $\mathrm{g}$ for $3 \mathrm{~min}$. The supernatant was used as the DNA template solution in the PCR. The primer pairs with the sequences of 5'CTC CAT AAA GGT GAC CCT 3' and 5'CAG CMG CCG CGG TAA TWC 3' was designed to specifically amplify a $938 \mathrm{bp}$ fragment of the $16 \mathrm{~S}$ rRNA gene for the detection of Listeria genus. Another set of primer pairs with the sequences of 5'CCT AAG ACG CCA ATC GAA 3' and 5'AAG CGC TTG CAA CTG CTC 3 ' was designed to amplify a $702 \mathrm{bp}$ fragment of the listeriolysin $\mathrm{O}$ (LLO) gene for the detection of $L$. monocytogenes. All the primers were obtained from Bio-Diagnostics Sdn Bhd, Invitrogen Corporation.

The PCR amplification was performed in $25 \mu \mathrm{L}$ reaction mixtures containing $5 \mu \mathrm{L}$ of $5 \mathrm{x}$ PCR buffer, $1.5 \mu \mathrm{L}$ of $25 \mathrm{mM} \mathrm{MgCl}_{2}, 0.2 \mu \mathrm{L}$ of $10 \mathrm{mM}$ of deoxynucleoside triphosphate mix, $0.3 \mu \mathrm{L}(1.5 \mathrm{U})$ of Taq DNA Polymerase, $0.5 \mu \mathrm{L}$ of each primers, $14 \mu \mathrm{L}$ of sterile distilled water and $2 \mu \mathrm{L}$ of DNA template. All the PCR reagents were purchased from Promega, Research Instruments, USA. Thermal cycling was carried out in Veriti ${ }^{\mathrm{TM}}$ 96-Well Thermal Cycler (Applied Biosystems, Foster City, CA, USA) by using the thermocycler conditions: initial denaturation at $94{ }^{\circ} \mathrm{C}$ for $5 \mathrm{~min}, 30$ cycles of denaturation at $94{ }^{\circ} \mathrm{C}$ for $30 \mathrm{~s}$, annealing at $53{ }^{\circ} \mathrm{C}$ for $1 \mathrm{~min}$, and extension at $72{ }^{\circ} \mathrm{C}$ for $2 \mathrm{~min}$, and followed by a final extension at $72^{\circ} \mathrm{C}$ for $7 \mathrm{~min}$.

For visualization of PCR products, $3 \mu \mathrm{L}$ of amplified PCR products was loaded in $1.0 \%$ agarose gel and run at $100 \mathrm{~V}$ for $28 \mathrm{~min}$. Then, the agarose gel was stained with $0.1 \mu \mathrm{g} \mathrm{mL}^{-1}$ of ethidium bromide and viewed using the Gel Documentation System (SynGene). A DNA-molecular ladder (100 bp ladder) (Vivantis Technologies, Selangor, Malaysia) was included in each gel.

\section{Results}

A total of 63 beef offal samples were examined for prevalence and microbial load of $L$. monocytogenes by using MPN-PCR method. The prevalence of L. monocytogenes in beef offal was $33.33 \%$ (21 positive samples out of 63 samples). Overall, the occurrence of L. monocytogenes was highest in beef lung $(50.00 \%)$ followed by beef tripe (46.67\%), beef liver (25.00\%), and beef intestine (22.22\%). There are zero occurrences of $L$. monocytogenes in beef spleen sample analyzed. The prevalence of $L$. monocytogenes in beef offal samples was tabulated in Table 1.

In this study, the target genes specific for L. monocytogenes produced PCR products of size $702 \mathrm{bp}$ and 938 bp respectively. Figure 1 shows a representative PCR amplification of the 16S rRNA and LLO genes for identification of Listeria genus and L. monocytogenes respectively. Apart from enumeration of the prevalence of $L$. monocytogenes in beef offal samples, microbial load (MPN/g) of L. monocytogenes was also calculated. From the Table 2, the maximum numbers of L. monocytogenes in beef offal collected from wet market $\mathrm{A}, \mathrm{B}$, and $\mathrm{C}$ were 
Table 1 - Prevalence of L. monocytogenes in beef offal samples purchased from Wet Market A, B, and C.

\begin{tabular}{|c|c|c|c|c|c|c|c|c|c|c|c|c|}
\hline \multirow[t]{2}{*}{ Beef offal } & \multicolumn{3}{|c|}{ Wet market A } & \multicolumn{3}{|c|}{ Wet market B } & \multicolumn{3}{|c|}{ Wet market $\mathrm{C}$} & \multicolumn{3}{|c|}{ Total } \\
\hline & $\mathrm{n}^{\mathrm{a}}$ & $\begin{array}{c}\text { PCR } \\
\text { positive }\end{array}$ & $\%^{\mathrm{c}}$ & $\mathrm{n}^{\mathrm{a}}$ & $\begin{array}{c}\text { PCR } \\
\text { positive }\end{array}$ & $\%^{\mathrm{c}}$ & $\mathrm{n}^{\mathrm{a}}$ & $\begin{array}{c}\text { PCR } \\
\text { positive }\end{array}$ & $\%^{\mathrm{c}}$ & $\mathrm{n}^{\mathrm{a}}$ & $\begin{array}{c}\text { PCR } \\
\text { positive }\end{array}$ & $\%^{\mathrm{c}}$ \\
\hline Liver & 5 & 0 & 0.00 & 5 & 3 & 60.00 & 6 & 1 & 16.67 & 16 & 4 & 25.00 \\
\hline Lung & 4 & 1 & 25.00 & 4 & 3 & 75.00 & 6 & 4 & 66.67 & 14 & 8 & 50.00 \\
\hline Intestine & 4 & 2 & 50.00 & 5 & 0 & 0.00 & $b_{-}$ & $b_{-}$ & $b_{-}$ & 9 & 2 & 22.22 \\
\hline Tripe & 5 & 2 & 40.00 & 5 & 3 & 60.00 & 5 & 2 & 40.00 & 15 & 7 & 46.67 \\
\hline Spleen & 4 & 0 & 0.00 & 5 & 0 & 0.00 & $\mathrm{~b}_{-}$ & $b_{-}$ & $b_{-}$ & 9 & 0 & 0.00 \\
\hline Total & 22 & 5 & 22.73 & 24 & 9 & 37.50 & 17 & 7 & 41.18 & 63 & 21 & 33.33 \\
\hline
\end{tabular}

${ }^{a} \mathrm{n}=$ Number of sample.

${ }^{\mathrm{b}}(-)=$ Sample not available.

${ }^{c}(\%)=$ Percentage.

Table 2 - Microbial load of L. monocytogenes (MPN/g) in beef offal samples purchased from Wet Market A, B, and C.

\begin{tabular}{|c|c|c|c|c|c|c|c|c|c|}
\hline \multirow[t]{2}{*}{ Beef offal } & \multicolumn{3}{|c|}{ Wet Market A } & \multicolumn{3}{|c|}{ Wet Market B } & \multicolumn{3}{|c|}{ Wet Market C } \\
\hline & $\operatorname{Min}^{\mathrm{a}}$ & $\operatorname{Med}^{\mathrm{b}}$ & $\operatorname{Max}^{\mathrm{c}}$ & $\operatorname{Min}^{\mathrm{a}}$ & $\mathrm{Med}^{\mathrm{b}}$ & $\operatorname{Max}^{\mathrm{c}}$ & $\operatorname{Min}^{a}$ & $\mathrm{Med}^{\mathrm{b}}$ & $\operatorname{Max}^{\mathrm{C}}$ \\
\hline Liver & $<3$ & $<3$ & $<3$ & $<3$ & 6.2 & $>2, x 400$ & $<3$ & $<3$ & 14 \\
\hline Lung & $<3$ & $<3$ & 3.6 & $<3$ & $<3$ & 3 & $<3$ & $<3$ & 9.3 \\
\hline Intestine & $<3$ & $<3$ & 6 & $<3$ & $<3$ & $<3$ & ${ }_{-}^{\mathrm{d}}$ & - & - \\
\hline Tripe & $<3$ & $<3$ & 9.1 & $<3$ & 3.6 & 23 & $<3$ & $<3$ & 3.0 \\
\hline Spleen & $<3$ & $<3$ & $<3$ & $<3$ & $<3$ & $<3$ & - & - & - \\
\hline Average & $<3$ & $<3$ & 9.1 & $<3$ & $<3$ & $>2,400$ & $<3$ & $<3$ & 14 \\
\hline
\end{tabular}

${ }^{\mathrm{a}} \mathrm{Min}=$ Minimun MPN/g value.

${ }^{\mathrm{b}} \mathrm{Med}=$ Median MPN/g value.

${ }^{\mathrm{c}} \mathrm{Max}=$ Maximum MPN/g value.

${ }_{-}{ }_{-}=$Sample not available.

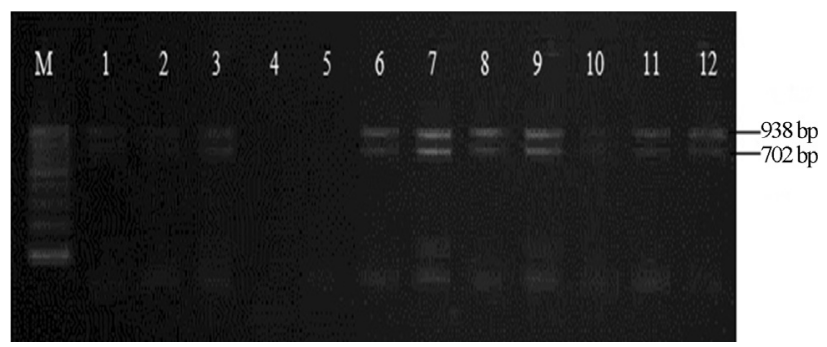

Figure 1 - Representative PCR amplification of the 16S rRNA and LLO genes for identification of Listeria spp. (genus) (938 bp) and Listeria monocytogenes (702 bp). Lane M shows the 100 bp DNA marker. Lane 5 and 6 show negative and positive control respectively. Lane 1 to 3 and lane 7 to 12 show L. monocytogenes positive samples whereas Lane 4 shows $L$. monocytogenes negative sample.

9.1 MPN/g, > 2,400 MPN/g, and $14 \mathrm{MPN} / \mathrm{g}$ respectively. Microbial load of $L$. monocytogenes in beef offal samples was summarized in Table 2.

\section{Discussion}

It was not surprising that $L$. monocytogenes was detected in the beef offal as slaughtered animals are recog- nized as reservoirs of foodborne pathogens (Mead, 2007). From Table 1, it showed that prevalence level of L. monocytogenes in beef offal may vary from low to high. This is mainly due to the different handling practices carried out in those wet markets. Generally, contamination can happen in many ways such as the use of unhygienic containers during transportation and distribution, improper food handling practices, cross-contamination from other contaminated foods or from infected field workers at the market (Chai et $a l ., 2007)$. Other than hygiene problems, storage temperature is also known to be closely related with the distribution of foodborne pathogens (Su and Liu, 2007). Storage of beef offal under refrigeration conditions is limited in controlling the initial microbial load of L. monocytogenes. Due to the psychrotrophic characteristic, they can remain viable and proliferate in the cold conditions. Therefore, it is reasonable to believe that the longer holding time for the beef offal to be sold out, the higher the microbial load of $L$. monocytogenes in beef offal.

The PCR technique which employs an enzyme and oligonucleotide primers was found to be simple, rapid, less laborious, and more reliable as compared to the conventional plating method. PCR protocol designed for this study 
is species specific and highly sensitive, which works based on virulent gene, LLO gene that present only in L. monocytogenes (Mengaud et al., 1988). The primers used were specifically designed for detection of $L$. monocytogenes as they only amplified a 702 bp region in the LLO gene (Aznar and Alarcón, 2003).

The presence of $L$. monocytogenes in beef offal samples analyzed in this study indicated that $L$. monocytogenes can act as possible vehicles of infection for foodborne listeriosis. Unhygienic practices during handling, distribution, and storage are believed to worsen this scenario. Although foodborne outbreak of listeriosis in Malaysia is rare, it does not mean that listeriosis will not occur since studies showed that $L$. monocytogenes had been isolated from wide range of foods. Listeria infection is rarely reported as it is not among the more commonly notifiable bacterial infections such as Salmonella and Escherichia infection. Besides, epidemiology of listeriosis is being complicated and symptoms such as flu-like illness or gastroenteritis will cause the incidence of listeriosis become more difficult to be identified (Bortulussi 2008). Thus, high risk groups such as pregnant women, elderly people and immune-compromised patients advised to avoid consume any partially or undercooked beef offal because inadequate heat treatment is unable to completely destroy L. monocytogenes and other foodborne pathogens present. Further studies to understand the growth and sources of contamination of L. monocytogenes in beef offal during slaughtering, distribution and storage can be carried out, in order to develop a food safety risk assessment model to estimate the risks of listeriosis associated with beef offal.

\section{Acknowledgments}

This study was supported by Grant-in-Aid for Scientific Research (KAKENHI 191010) from the Japan Society for the Promotion of Sciences.

\section{References}

Arumugaswamy RK, Rahmat Ali GR, Hamid SN (1994) Prevalence of Listeria monocytogenes in foods in Malaysia. Int J Food Microbiol 23:117-121.

Aznar R, Alarcón B (2003) PCR detection of Listeria monocytogenes: a study of multiple factors affecting sensitivity. J Appl Microbiol 95:958-966.
Berche P (2005) Pathophysiology and epidemiology of listeriosis. Bull Acad Nat Med 189:507-521.

Bortulussi R (2008) Listeriosis: A primer. Public Health. Can Med Assoc J 179:795-797.

Broome CV, Gellin B, Schwartz B (1990) Epidemiology of listeriosis in the United States. In: A.J. Miller, J.L. Smith, G.A. Somkuti, (eds) Foodborne Listeriosis. Elsevier Science, New York, pp 61-65.

Chai LC, Tunung R, Usha MR, Jurin WG, Fatimah AB, Farinazleen MG (2007) Thermophilic campylocbacter spp. in salad vegestables in Malaysia. Int $\mathbf{J}$ Food Microbiol 117:106-111.

Dalton CB, Austin CC, Sobel J (1997) An outbreak of gastro- enteritis and fever due to Listeria monocytogenes in milk. New Engl J Med 336:100-105.

Endang P, Radu S, Ismail A, Cheah YK, Maurice L (2003) Characterization of Listeria monocytogenes isolated from chicken meat: Evidence of conjugal transfer of plasmid- mediated resistance to antibiotic. J Anim Vet Adv 2:237-246.

Jeyaletchumi P, Tunung R, Margaret SP, Radu S, Farinazleen MG, Cheah YK (2010) Review Article: Detection of Listeria monocytogenes in foods. Int Food Res J 17:1-11.

Jeyaletchumi P, Tunung R, Margaret SP, Radu S, Farinazleen MG, Cheah YK, Mitsuaki N, Yoshitsugu N, Pradeep KM (2010) Listeria monocytogenes in raw salad vegetables sold at retail level in Malaysia. J Food Control 21:774-778.

Lyytikäinen O, Autio T, Maijala R (2001) An outbreak of Listeria monocytogenes serotype $3 \mathrm{a}$ infections from butter in Finland. J Infect Dis 181:1838-1841.

Liu D (2006) Identification, subtyping and virulence determination of Listeria monocytogenes, an important foodborne pathogen. J Med Microbiol 55:645-659.

Makino SI, Kawamoto K, Takeshi K, Okada Y, Yamasaki M, Yamamoto S, Igimi S (2005) An outbreak of food-borne listeriosis due to cheese in Japan, during 2001. Int J Food Microbiol 104:189-196.

Mead GC (2007) Sampling methods for poultry-meat products. In: G.C. Mead (ed) Microbiological Analysis of Red Meat, Poultry and Eggs. CRC Press, Washington, pp 148-164.

Mengaud J, Vincente MF, Chenevert J, Pereira JM, Geoffrey C, Gicquel-Sanzey B, Baquero F, Perez-Diaz JC, Cossart P (1988) Expression in Escherichia coli and sequence analysis of the listeriolysin $\mathrm{O}$ determinant of Listeria monocytogenes. Infection and Immunity 56:766-772.

Painter J, Slutsker L (2007) Listeriosis in humans. In: E.T. Ryser, E.H. Marth (eds) Listeria, Listeriosis and Food Safety. CRC Press, Boca Raton, pp 85-109.

Su YC, Liu C (2007) Vibrio parahaemolyticus: A concern of seafood safety. Food Microbiol 24:549-598.

All the content of the journal, except where otherwise noted, is licensed under a Creative Commons License CC BY-NC. 